Vol. 2 No.2 Juni 2020

Ensiklopedia Social Review

http://jurnal.ensiklopediaku.org

\title{
LEMBAGA PERWAKILAN DAERAH DALAM NEGARA DEMOKRASI
}

\section{ERRY GUSMAN}

Fakultas Hukum Universitas Muhammadiyah Sumatera Barat

errygusman@gmail.com

\begin{abstract}
A hallmark of constitutional democracy is the idea that a democratic government is a government that has limited powers and is not justified in acting arbitrarily against its citizens. State power is divided in such a way that opportunities for abuse are reduced. By way of handing it over to several people or bodies and not centralizing the power of government in one hand or one body. Juridical formulation of these principles is famous for Rechstaat (rule of law) and Rule of Law. In the view of democratic groups that base themselves on communist ideology, they always act ambivalent towards the state. The state is seen as a coercive tool that will eventually disappear by itself, after the emergence of communist society. Karl Marx and Engels, the State is nothing but a machine used by one class to act against another class and the state is only a transitional institution used in the struggle to oppress opponents with violence. The state will eventually disappear when communism is reached because no one is oppressed.
\end{abstract}

Keywords: Regional Representative Body, State, Democracy.

Abstrak: Ciri khas dari demokrasi konstitusional ialah gagasan bahwa pemerintah yang demokratis adalah pemerintah yang terbatas kekuasaannya dan tidak dibenarkan bertindak sewenang-wenang terhadap warga negaranya. Kekuasaan negara dibagi sedemikian rupa sehingga kesempatan penyalahgunaan diperkecil. Dengan cara menyerahkannya kepada beberapa orang atau badan dan tidak memusatkan kekuasaan pemerintahan dalam satu tangan atau satu badan. Perumusan yuridis dari prinsipprinsip ini terkenal dengan Rechstaat (negara hukum) dan Rule of Law. Dalam pandangan kelompok aliran demokrasi yang mendasarkan dirinya atas paham komunis selalu bersikap ambivalent terhadap negara. Negara dianggapnya sebagai suatu alat pemaksa yang akhirnya akan melenyap dengan sendirinya, setelah muncul masyarakat komunis. Karl Marx dan Engels, Negara tak lain tak bukan hanyalah mesin yang dipakai oleh satu kelas untuk menindak kelas yang lain dan negara hanya merupakan suatu lembaga transisi yang dipakai dalam perjuangan untuk menindas lawan-lawan dengan kekerasan. Negara akhirnya akan lenyap pada saat komunisme tercapai karena tidak ada lagi yang ditindas.

Kata Kunci: Lembaga Perwakilan Daerah, Negara, Demokrasi.

\section{A. Pendahuluan}

Undang-undang Nomor 23 Tahun 2014 tentang Pemerintahan Daerah sebagaimana telah diubah dengan Undang-Undang Nomor 9 Tahun 2015 (UU Pemda) mencoba meletakkan kembali dasar-dasar politik otonomi yang lebih wajar sesuai dengan kehendak konstitusi. Undang-undang baru ini menghendaki titik berat penyelenggaraan pemerintahan ada pada daerah. Segala "kepentingan masyarakat" pada dasarnya diatur dan diurus daerah, kecuali terhadap hal-hal yang oleh undangundang ditetapkan atau diatur dan diurus pusat yaitu politik luar negeri, pertahanan 
keamanan, peradilan, moneter dan fiskal, agama, dan beberapa kebijakan tingkat nasional tertentu. Demikian pula mengenai perwujudan kedaulatan rakyat.

Pemerintahan daerah disusun, diisi, dan diawasi menurut prinsip yang lebih demokratik dengan meletakkan tanggungjawab politik yang lebih besar kepada rakyat daerah, seperti pertanggungjawaban bupati atau walikota kepada DPRD setempat. Perimbangan keuangan disusun untuk lebih memberdayakan daerah (UU No. 33 Tahun 2004). Hak daerah-daerah untuk membela kepentingan peraturan daerah, perluasan wewenang di bidang kepegawaian, termasuk hal-hal yang mencerminkan politik otonomi baru yang semestinya di tempuh di masa depan (Bagir Manan, 2004). Susunan Pemerintahan Daerah dan Hak Otonomi meliputi DPRD dan Pemerintah Daerah. Pemisahan DPRD dari Pemerintah Daerah dengan maksud untuk lebih memberdayakan DPRD dan meningkatkan pertanggungjawaban Pemerintah Daerah kepada Rakyat. Oleh karena itu hak-hak DPRD cukup luas dan diarahkan untuk menyerap serta menyalurkan aspirasi masyarakat agar menjadi kebijakan daerah, serta melakukan fungsi pengawasan.

Dalam menjalankan peran perwakilan rakyat di daerah, anggota DPRD Secara normatif adalah pelaku utama perumusan kebijakan publik di daerahnya. Untuk mengemban peran ini, DPRD sebagai pemegang kekuasaan legislatif harus bertanggung jawab untuk ikut menentukan isi kebijakan daerah serta memastikan bahwa kebijakan yang ditempuh pemerintah benar-benar kebijakan yang dikehendaki masyarakat di daerah. Untuk dapat memainkan peranan yang dikehendaki oleh masyarakat, DPRD sebagai lembaga legislatif daerah mempunyai wewenang, kewajiban dan hak. Secara umum ketiga hal itu mempunyai pengertian yang berbeda. Wewenang merupakan kemampuan atau kecakapan untuk menyandang hak dan kewajiban-kewajiban merupakan pembatasan dan beban yang harus dilaksanakan menurut hukum. Sedangkan hak merupakan kepentingan yang harus dipenuhi dan dilindungi oleh hukum.

Pengaturan mengenai tugas dan wewenang DPRD diatur secara tegas oleh Pasal 101 ayat (1) UU No. 23 Tahun 2014 menetapkan bahwa: DPRD provinsi mempunyai tugas dan wewenang: a) membentuk Perda Provinsi bersama gubernur; b) membahas dan memberikan persetujuan Rancangan Perda Provinsi tentang APBD Provinsi yang diajukan oleh gubernur; c) melaksanakan pengawasan terhadap pelaksanaan Perda Provinsi dan APBD provinsi; d) memilih gubernur; e) mengusulkan pengangkatan dan pemberhentian gubernur kepada Presiden melalui Menteri untuk mendapatkan pengesahan pengangkatan dan pemberhentian; f) memberikan pendapat dan pertimbangan kepada Pemerintah Daerah provinsi terhadap rencana perjanjian internasional di Daerah provinsi; g) memberikan persetujuan terhadap rencana kerja sama internasional yang dilakukan oleh Pemerintah Daerah provinsi; h) meminta laporan keterangan pertanggungjawaban gubernur dalam penyelenggaraan Pemerintahan Daerah provinsi; i) memberikan persetujuan terhadap rencana kerja sama dengan Daerah lain atau dengan pihak ketiga yang membebani masyarakat dan Daerah provinsi; dan j) melaksanakan tugas dan wewenang lain yang diatur dalam ketentuan peraturan perundang-undangan.

Menjalankan tugas dan wewenang sebagaimana maksud Pasal 101 ayat (1) UU Nomor 23 Tahun 2014, dalam Pasal 108 UU No. 23 Tahun 2014 dinyatakan bahwa: Anggota DPRD provinsi berkewajiban: a) memegang teguh dan mengamalkan Pancasila; b) melaksanakan Undang-Undang Dasar Negara Republik Indonesia Tahun 1945 dan menaati ketentuan peraturan perundang-undangan; c) mempertahankan dan memelihara kerukunan nasional dan keutuhan Negara Kesatuan Republik Indonesia; d) E-ISSN: 2657-0300 Lembaga Penelitian dan Penerbitan Hasil Penelitian Ensiklopedia 103 
mendahulukan kepentingan negara di atas kepentingan pribadi, kelompok, dan golongan; e) memperjuangkan peningkatan kesejahteraan rakyat; f) menaati prinsip demokrasi dalam penyelenggaraan Pemerintahan Daerah; g) menaati tata tertib dan kode etik; h) menjaga etika dan norma dalam hubungan kerja dengan lembaga lain dalam penyelenggaraan Pemerintahan Daerah provinsi; i) menyerap dan menghimpun aspirasi konstituen melalui kunjungan kerja secara berkala; j) menampung dan menindaklanjuti aspirasi dan pengaduan masyarakat; dan k) memberikan pertanggungjawaban secara moral dan politis kepada konstituen di daerah pemilihannya.

Untuk melaksanakan tugas dan wewenang sebagaimana dimaksud Pasal 101 ayat (1) UU No. 23 Tahun 2014, dalam Pasal 160 UU No. 23 Tahun 2014 dinyatakan bahwa: Anggota DPRD provinsi mempunyai hak: a) mengajukan rancangan Perda Provinsi; b) mengajukan pertanyaan; c) menyampaikan usul dan pendapat; d) memilih dan dipilih; e) membela diri; f) imunitas; g) mengikuti orientasi dan pendalaman tugas; h) protokoler; dan i) keuangan dan administratif. Selain lembaga perwakilan di daerah, DPRD mempunyai peranan besar dalam mewarnai jalannya pemerintahan daerah otonom. Dengan peranan ini, aspek responsibilitas dalam pelaksanaan tugas-tugas DPRD menjadi salah satu faktor penentu terhadap makna dan kemanfaatan Pemerintah daerah bagi terwujudnya masyarakat yang sejahtera, berdaulat dan mampu berpartisipasi dalam penyelenggaraan pemerintahan dan pembangunan. Pemahaman ini sekaligus memberikan tanggung jawab kepada DPRD untuk ikut menentukan isi kebijakan bagi pemerintah daerah yang bersangkutan dan atau untuk menegakkan prinsip demokrasi. Artinya bahwa, DPRD harus memastikan kebijakan yang ditempuh pemerintah sesuai aspirasi yang dikehendaki rakyat.

Dalam UU No. 23 Tahun 2014, keberadaan DPRD sangat diperlukan sebagai pemegang kekuasaan legislatif (atau institusi legislatif) yang merupakan representasi rakyat di suatu daerah otonom. Sebagai pemegang kekuasaan legislatif di daerah, DPRD diserahkan tugas dan kewenangan yang menyangkut urusan di bidang politik, yaitu perumusan kebijakan publik dan pelaksanaan pengawasan. Dalam perumusan kebijakan publik, DPRD sebagai pemegang kekuasaan legislatif diserahkan tugas dan wewenang yang pokok. Pertama, karena DPRD secara normatif adalah pelaku utama perumusan kebijakan publik di daerah, DPRD harus bertanggung jawab untuk menentukan isi kebijakan daerah, sekalipun pelaksanaan penetapan kebijakankebijakan publik di daerah ada pada Kepala Daerah berikut jajaran birokrasi pemerintahannya. Kedua, DPRD mengambil dan menetapkan kebijakan sebagai institusi, artinya DPRD bukanlah sekedar perwakilan kelompok masyarakat melainkan perwakilan aspirasi dalam memastikan bahwa kebijakan yang ditempuh oleh pemerintah sesuai dengan aspirasi yang berkembang di masyarakat.

Ketiga, kebijakan publik pada dasarnya adalah serangkaian tindakan termasuk di dalamnya penetapan sesuatu atau serangkaian keputusan-keputusan oleh pejabat yang memegang otoritas penyelenggaraan pemerintahan dalam rangka mencapai suatu tujuan publik. Kendati DPRD sebagai aktor penting dalam perumusan kebijakan publik di daerah, DPRD harus dapat membentuk sparing partner dengan kepala daerah beserta perangkatnya, dalam melaksanakan tugas dan wewenang tersebut misalnya: a) DPRD bersama Pemerintah Daerah membentuk Peraturan Daerah; b) DPRD bersama Pemerintah Daerah menetapkan Anggaran Pendapatan dan Belanja Daerah (APBD); dan c) DPRD memberikan pendapat dan pertimbangan kepada pemerintah terhadap 
rencana perjanjian internasional yang menyangkut kepentingan daerah. Dalam Pasal 100 ayat (1) UU No. 23 Tahun 2014 diatur tugas dan wewenang DPRD untuk melaksanakan pengawasan terhadap: a) pelaksanaan Perda provinsi dan peraturan gubernur; b) pelaksanaan peraturan perundang-undangan lain yang terkait dengan penyelenggaraan Pemerintahan Daerah provinsi; dan c) pelaksanaan tindak lanjut hasil pemeriksaan laporan keuangan oleh Badan Pemeriksa Keuangan.

Dengan tugas dan wewenang ini, DPRD diharapkan mampu memainkan peranannya secara optimal sebagai institusi pengemban fungsi kontrol terhadap jalannya pemerintahan di daerah. Tujuannya adalah terwujudnya pemerintahan daerah yang efisien, efektif, bersih, berwibawa dan terbebas dari berbagai praktek-praktek yang berindikasi korupsi, kolusi, nepotisme (KKN). Tugas dan wewenang pengawasan yang dimaksud dalam ketentuan ini, berbeda dengan tugas pengawasan yang dilakukan oleh perangkat pengawas fungsional. Tugas dan wewenang pengawasan yang dilakukan DPRD berada dalam dimensi politik. Sedangkan tugas pengawasan yang dilakukan perangkat fungsional berada dalam dimensi administrasi Hal ini berarti, tugas pengawasan oleh DPRD lebih menekankan pada segi hubungan antara penggunaan kekuasaan oleh eksekutif dengan kondisi kehidupan rakyat di daerah.

\section{B. Metodologi Penelitian}

Penelitian yang dilaksanakan oleh penulis dengan mengunakan metode penelitian hukum dalam ruang lingkup deskriptif yaitu suatu usaha untuk menggambarkan tentang lembaga perwakilan daerah dalam negara demokrasi. Penelitian yang dilakukan oleh penulis dengan mengunakan pendekatan yuridis normatif atau dengan cara meneliti bahan Pustaka. Dalam hal penelitian yang dilakukan dengan cara mempelajari bahan- bahan hukum primer dan sekunder yang nantinya akan dijadikan pedoman dalam memahami dan menganalisis permasalahan yang dibahas, sedangkan sebagai pendukung utama digunakan pendekatan empris, dimana juga akan diteliti penerapan hukum dalam praktis khususnya penerapan hukum yang menyangkut lembaga perwakilan daerah dalam negara demokrasi.

\section{Hasil dan Pembahasan}

Sejarah demokrasi memiliki perjalanan yang panjang dan penuh dengan aliran pemikiran dari beberapa tokoh atau filosof. Selain itu, perjalanan demokrasi juga ditandai dengan jatuh bangunnya sebuah negara dalam mengapresiasi sistem yang baru. Beberapa yang perlu untuk dicatat adalah masa renaissance di Eropa, revolusi Perancis dan beberapa pengalaman di negara lain. Satu yang patut disimpulkan dari keterkaitan ini adalah sebuah masyarakat atau negara yang akan mengadopsi sistem demokrasi, setelah sebelumnya memakai sistem yang lama, memerlukan waktu yang panjang dan penuh dengan pertentangan yang tak jarang menimbulkan pertumpahan darah. Demokrasi tak lahir begitu saja. Setelah sebelumnya berlayar dari peradaban Yunani, yang merupakan akar lahirnya berbagai ilmu pengetahuan, para pemikir lebih menitikberatkan demokrasi sebagai sebuah konsep untuk menuju kehidupan bernegara yang lebih baik dan bermartabat, meski ada beberapa pemikir yang menilai demokrasi bukan sebagai jalan untuk menuntun ke arah yang lebih baik.

Menurut Hans Kelsen (2006), ide demokrasi berawal dari keinginan manusia untuk menikmati kebebasan (free will). Kebebasan yang mungkin didapat dalam masyarakat, dan khususnya di dalam negara, tidak bisa berarti kebebasan dari setiap ikatan, tetapi hanya bisa berupa kebebasan dari satu macam ikatan tertentu. Misalnya, kebebasan politik adalah kebebasan di bawah tatanan sosial, adalah penentuan E-ISSN: 2657-0300 Lembaga Penelitian dan Penerbitan Hasil Penelitian Ensiklopedia $\quad 105$ 
kehendak sendiri dengan jalan turut serta dalam pembentukan tatanan sosial. Kebebasan politik adalah kemerdekaan dan kemerdekaan adalah kemandirian. Masih dalam pandangan Hans Kelsen, kehendak masyarakat, di dalam negara demokrasi, selalu dibuat dalam pembahasan berturut-turut antara mayoritas dan minoritas melalui kaji pendapat secara bebas dan kaji peraturan tertentu mengenai suatu pokok masalah. Pembahasan ini berlangsung tidak hanya di parlemen, tetapi juga berlangsung pada pertemuan-pertemuan politik, dalam surat kabar, buku dan sarana-sarana pendapat umum yang lain. Suatu negara demokrasi tanpa suatu pendapat umum merupakan suatu pertentangan istilah. Manakala pendapat umum hanya dapat muncul jika kebebasan intelektual, kebebasan berbicara, kebebasan pers, kebebasan beragama dijamin, maka demokrasi berhimpitan dengan liberalisme politik dan walaupun tidak mesti dengan liberalisme ekonomi.

Konsepsi mengenai demokrasi tak akan menarik jika tidak melihat dua pandangan kontradiktif dari Karl Marx dan Max Weber. Marx mengatakan bahwa demokrasi mutlak bagi keberadaan sebuah negara. Demokrasi yang paling tepat menurut Karl Marx adalah demokrasi yang menekankan pemerintahan parlementer, pembagian kekuasaan dan kesetaraan di bawah hukum negara, dan bukan negara dengan berdasarkan pada demokrasi borjuis. Meskipun memang bukan sebagai sebuah pemikir tentang konsep negara, namun Marx memberikan batasan tertentu mengenai konsep negara yang diyakininya menjadi sebuah solusi. Meski dalam beberapa hal konsep Marx tentang negara dan demokrasi ini belum menemui titik terang karena tidak adanya penjelasan yang khusus terhadap poin negara dan demokrasi dalam pemikiran Marx. Pemikiran Marx tentang negara kemudian diterjemahkan secara bebas oleh Lenin dan Stalin yang justru membawa dampak mengerikan terhadap perkembangan demokrasi.

Sejarah demokrasi sebuah negara tidak berjalan dengan sendirinya. Menurut pendapat Burrington Moore, rumusan jalur sebuah negara menuju demokrasi dapat dirumuskan sebagai berikut: a) Demokrasi muncul dalam kondisi dimana segolongan borjuasi yang kuat dan independen muncul dengan kepentingan yang bertentangan dengan rezim masa lalu dan mampu menerapkan kontrol atas kebijaksanaan nasional (sementara pada waktu yang sama suatu pertimbangan kekuatan antara kelas atas pemilik tanah dengan negara tetap dipertahankan) dan dimana pengaruh petani lemah sekali atau bahkan tidak ada karena ditransformasikan atau dihancurkan oleh para tuan tanah dan pihak-pihak lain yang terlibat dalam proses komersialisasi pertanian; b) Jalur yang menghasilkan fasisme (seperti di Jepang pada tahun 1930-an). Fasisme muncul dimana saat borjuasi kota relatif lemah dan didominasi oleh negara dan bertumpu pada kelas atas pemilik tanah yang dominan untuk mensponsori komersialisasi pertanian melalui dominasi mereka atas negara, yang memaksakan disiplin perburuhan kepada para petani; c) Jalur yang menghasilkan revolusi komunis (seperti di Cina pada tahun 1940-an). Revolusi komunis terjadi karena borjuasi kita lemah dan didominasi oleh negara, kaitan antara petani dan tuan tanah lemah, tuan tanah tidak mampu melakukan komersialisasi pertanian, dan petani yang bersatu padu berhasil membangun aliansi yang memiliki kecakapan organisasi; dan d) Jalur yang menarik adalah apa yang telah ditempuh oleh negara India. Penyebab keberhasilan India mengembangkan demokrasi justru disebabkan oleh pemerintahan kolonial Inggris yang sempat menjajah India. Penyebab pertama, negara kolonial menciptakan kondisi struktural yang menguntungkan bagi pertumbuhan demokrasi parlementer dengan cara memisahkan 
kelas atas pemilik tanah dengan kelas-kelas komersial dan profesional-profesional kota yang baru muncul. Kedua, gagasan politik Inggris, termasuk gagasan politik perwakilan, merasuk pada pemikiran anggota kelas komersial dan profesional itu ketika mereka bersekolah. Ketiga, ketika kelas-kelas komersil dan profesional tersebut mulai pada gagasan untuk membentuk gerakan politik (nasionalis) untuk mencapai tujuan-tujuan politik, mereka didorong ke arah akomodasi dengan kelas petani untuk meningkatkan efektivitas gerakan politik mereka.

Kita mengenal bermacam-macam istilah demokrasi. Ada yang dinamakan demokrasi konstitusionil, demokrasi parlementer, demokrasi terpimpin, demokrasi rakyat, demokrasi Soviet, demokrasi nasional. Semua konsep ini memakai istilah demokrasi yang menurut asal kata berarti "rakyat berkuasa" atau "government or rule by the people". Kata Yunani demos berarti rakyat, kratos/kratein berarti kekuasaan/berkuasa. Menurut tafsir R. Kranenburg di dalam bukunya "Inleiding in de vergelijkende staatsrechtwetenschap", perkataan demokrasi yang terbentuk dari dua pokok kata Yunani di atas, maknanya adalah cara memerintah oleh rakyat. Ditinjau lebih dalam lagi tentang makna demokrasi ini ialah cara pemerintahan yang dilakukan oleh dan atas nama seorang diri (misalnya oleh seorang raja yang berkuasa mutlak). Juga tidak termasuk dalam pengertian demokrasi ialah cara pemerintahan negara yang disebut "autocratie" atau "oligarchie", yakni pemerintahan yang dilakukan oleh segolongan kecil manusia saja, yang menganggap dirinya sendiri tercakup dan berhak untuk mengambil dan melakukan segala kekuasaan di atas segenap rakyat. Cara pemerintahan yang bagaimanakah yang masuk dalam arti demokrasi itu? Menurut M. Duverger di dalam bukunya "les Regimes Politiques", demokrasi itu termasuk cara pemerintahan dimana golongan yang memerintah dan golongan yang diperintah itu adalah sama dan tidak terpisah-pisah. Artinya satu sistem pemerintahan negara dimana dalam pokoknya semua orang (rakyat) adalah berhak sama untuk memerintah dan juga untuk diperintah.

Di antara sekian banyak aliran pikiran yang dinamakan demokrasi ada dua kelompok aliran yang paling penting, yaitu demokrasi konstitusional dan satu kelompok aliran yang menamakan dirinya demokrasi, tetapi yang pada hakikatnya mendasarkan dirinya atas komunisme. Perbedaan fundamental, di antara kedua aliran itu ialah bahwa demokrasi konstitusional mencita-citakan pemerintah yang terbatas kekuasaannya, suatu negara hukum (rechstaat), yang tunduk pada rule of law. Sebaliknya demokrasi yang mendasarkan dirinya atas komunisme mencita-citakan pemerintah yang tidak boleh dibatasi kekuasaannya (machtstaat), yang bersifat totaliter. Henry B. Mayo dalam bukunya Introduction to Democratic Theory memberi definisi demokrasi sebagai sistem politik sebagai berikut: "Sistem politik yang demokratis ialah dimana kebijaksanaan umum ditentukan atas dasar mayoritas oleh wakil-wakil yang diawasi secara efektif oleh rakyat dalam pemilihan-pemilihan berkala yang didasarkan atas prinsip kesamaan politik dan diselenggarakan dalam suasana terjaminnya kebebasan politik" (a democratic political system is one in which public policies are made on a majority basis, by representatives subject to effective popular control at periodic elections which are conducted on the principle of political equality and under conditions of political freedom).

Lebih lanjut B. Mayo menyatakan bahwa demokrasi didasari oleh beberapa nilai, yakni: a) Menyelesaikan perselisihan dengan damai dan secara melembaga (institutionalized peaceful settlement of conflict): b) Menjamin terselenggaranya perubahan secara damai dalam suatu masyarakat yang sedang berubah (peaceful change in a changing society); c) Menyelenggarakan pergantian pimpinan secara 
teratur (orderly succession of rulers); d) Membatasi pemakaian kekerasan sampai minimum (minimum of coercion); e) Mengakui serta menganggap wajar adanya keanekaragaman (diversity) dalam masyarakat yang tercermin dalam keanekaragaman pendapat, kepentingan serta tingkah laku; dan f) Menjamin tegaknya keadilan. Untuk melaksanakan nilai-nilai demokrasi perlu diselenggarakan beberapa lembaga sebagai berikut: a) Pemerintahan yang bertanggung jawab; b) Suatu dewan perwakilan rakyat yang mewakili golongan-golongan dan kepentingan-kepentingan dalam masyarakat dan dipilih dengan pemilihan umum yang bebas dan rahasia dan atas dasar sekurangkurangnya dua calon untuk setiap kursi; c) Suatu organisasi politik yang mencakup satu atau lebih partai politik; d) Pers dan media massa yang bebas untuk menyatakan pendapat; dan e) Sistem peradilan yang bebas untuk menjamin hak-hak asasi dan mempertahankan keadilan.

Dalam perjalanan waktu, konsep rechtstaat telah mengalami perkembangan dari konsep klasik ke konsep modern. Sesuai dengan sifat dasarnya, konsep klasik disebut "klassiek liberale en democratische rechtstaat" yang sering disingkat saja dengan "democratische rechstaat". Konsep modern lazimnya disebut (terutama di Belanda) "sociale rechstaat" atau juga disebut "sociale-democratische rechtstaat". Sifatnya yang liberal bertumpu atas pemikiran kenegaraan dari John Locke, Montesqieu dan Immanuel Kant. Sifatnya yang demokratis, bertumpu atas pemikiran kenegaraan dari JJ Rousseau tentang kontrak sosial. Prinsip liberal bertumpu atas "liberty" (vrijheid) dan prinsip demokrasi bertumpu atas "equality" (gelijkheid). Liberty menurut Immanuel Kant adalah "the free selfassertion of each-limited only by the like liberty of all". Atas dasar itu "liberty" merupakan suatu kondisi yang memungkinkan pelaksanaan kehendak secara bebas dan hanya dibatasi seperlunya untuk menjamin koeksistensi yang harmonis antara kehendak bebas individu dengan kehendak bebas semua yang lain. Dari sinilah mengalir prinsip selanjutnya, yaitu freedom from arbitrary and unreasonable exercise of the power and authority. Konsep "equality" mengandung makna yang abstrak dan formal (abstract-formal equality) dan dari sini mengalir prinsip "one man one vote".

Atas dasar demokratis, rechstaat dikatakan sebagai "negara kepercayaan timbal balik (de staat ban het wederzijds vertrouwen), yaitu kepercayaan dari rakyat pendukungnya bahwa kekuasaan yang diberikan tidak akan disalahgunakan dan kepercayaan dari penguasa bahwa dalam batas kekuasaannya dia mengharapkan kepatuhan dari rakyat pendukungnya.Asas-asas demokratis yang melandasi rechstaat, menurut SW Couwenberg meliputi 5 asas, yaitu: a) Asas hak-hak politik (het beginsel van de politieke grondrechten); b) Asas mayoritas; c) Asas perwakilan; d) Asas pertanggungjawaban; dan e) Asas publik (openbaarheidsbeginsel). Atas dasar sifatsifat tersebut, yaitu liberal dan demokratis, ciri-ciri rechstaat adalah: a) Adanya undang-undang dasar atau konstitusi yang memuat ketentuan tertulis tentang hubungan antara penguasa dan rakyat; b) Adanya pembagian kekuasaan negara, yang meliputi: kekuasaan pembuatan undang-undang yang ada pada parlemen, kekuasaan kehakiman yang bebas yang tidak hanya menangani sengketa antara individu rakyat tetapi juga antara penguasa dan rakyat, dan pemerintah yang mendasarkan tindakannya atas undang-undang (wetmatig bestuur); c) Diakui dan dilindunginya hak-hak kebebasan rakyat (vrijheidsrechten van de burger).

Ciri-ciri di atas menunjukkan dengan jelas bahwa ide sentral daripada rechstaat adalah pengakuan dan perlindungan terhadap hak-hak asasi manusia yang bertumpu 
atas dasar prinsip kebebasan dan persamaan. Adanya undang-undang dasar akan memberikan jaminan konstitusional terhadap asas kebebasan dan persamaan. Adanya pembagian kekuasaan untuk menghindarkan penumpukan kekuasaan dalam satu tangan yang sangat cenderung kepada penyalahgunaan kekuasaan, berarti pemerkosaan terhadap kebebasan dan persamaan. Dengan adanya kekuasaan pembuatan undangundang yang dikaitkan dengan parlemen dimaksudkan untuk menjamin bahwa hukum yang dibuat adalah atas kehendak rakyat, dengan demikian hukum tersebut tidak akan memperkosa hak-hak rakyat, tetapi dikaitkan dengan asas mayoritas, kehendak rakyat diartikan sebagai kehendak golongan mayoritas.

Untuk mengetahui sebuah pemerintahan negara itu menjalankan sistem demokrasi atau tidak demokrasi, beberapa indikator ditunjukkan para ahli sebagai ukuran untuk disebut demokratis. Lyman Tower Sargent, memberikan poin-poin kunci sebagai unsur-unsur demokrasi, yaitu: a) Citizen involvement in political decision making; b) Some degree of equality among citizens; c) Some degree of liberty or freedom granted to or retained by citizens; d) A system of representation; e) An elektoral system majority role. Kemudian hasil konferensi "International Commission of Jurist" di Bangkok pada tahun 1965 menekankan bahwa di samping hak-hak politik bagi rakyat harus diakui pula adanya hak-hak sosial dan ekonomi, sehingga perlu dibentuk standar-standar dasar sosial ekonomi. Komisi ini dalam konferensi tersebut juga merumuskan syarat-syarat (ciri-ciri) pemerintahan yang demokratis di bawah Rule of Law (yang dinamis, baru) sebagai berikut: a) Perlindungan konstitusional, artinya selain menjamin hak-hak individu, konstitusi harus pula menentukan cara prosedural untuk meperoleh perlindungan atas hak-hak yang dijamin; b) Badan kehakiman yang bebas dan tidak memihak; c) Pemilihan umum yang bebas; d) Kebebasan menyatakan pendapat; e) Kebebasan berserikat/berorganisasi dan beroposisi; dan f) Pendidikan kewarganegaraan.

Telah dikemukakan, otonomi daerah bertalian dengan demokrasi, karena itu harus ada lembaga dan tata cara penyelenggaraan pemerintahan demokrasi di daerah. Sejalan dengan sistem demokrasi perwakilan, maka secara kelembagaan perlu ada badan perwakilan rakyat daerah yang dibentuk secara demokratik. Demikian pula penyelenggaraan pemerintahannya harus dijalankan pejabat, penentuan kebijakan, pertanggungjawaban, pengawasan, dan lain-lain. Mekanisme pemerintahan harus dilakukan dengan tata cara yang demokratik pula. Berdasarkan hal-hal tersebut lahirlah berbagai mekanisme demokratik, seperti sistem pemilihan anggota perwakilan, sistem pemilihan penyelenggara pemerintahan (bupati, walikota, gubernur), sistem hubungan tanggungjawab antara badan perwakilan dengan penyelenggara pemerintahan, dan lain sebagainya. Sebagai daerah otonom yang memerintah, mengatur, dan mengurus diri sendiri, pemerintahan daerah berhak membuat peraturan tingkat daerah sebagai peraturan perundang-undangan tingkat daerah.

\section{Penutup}

Lembaga perwakilan daerah dalam negara demokrasi perjalanan kebijakan baik di bidang pengaturan maupun penyelenggaraan otonomi sejak Indonesia merdeka. Seperti diutarakan terdahulu, selama merdeka, terutama empat puluh tahun terakhir (Orde Lama dan Orde Baru), berbagai cita dasar otonomi tidak terlaksana sebagaimana mestinya. Yang terjadi adalah suasana sentralisasi. Daerah-daerah dibuat sangat tergantung kepada pusat, baik dibidang keuangan, kepegawaian, politik, termasuk penentuan pimpinan daerah. Inilah sesungguhnya latar belakang ketidakpuasan dan 
Vol. 2 No.2 Juni 2020

Ensiklopedia Social Review

http://jurnal.ensiklopediaku.org

pergolakan daerah yang akhir-akhir disebut sebagai ancaman disintegrasi negara dan bangsa.

\section{Daftar Pustaka}

Bagir Manan, Menyongsong Fajar Otonomi Daerah, PSH FH UII, Yogyakarta, 2004.

Hans Kelsen, Teori Umum Tentang Hukum dan Negara, Nusamedia dan Nuansa, Bandung, 2006.

Ronald H. Chicote, Teori Perbandingan Politik, Penelusuran Paradigma, PT Raja Grafindo Persada, Jakarta, 2003.

Mochtar Mas'oed, Negara, Kapital dan Demokrasi, cetakan kedua, Pustaka Pelajar, Yogyakarta, 1999.

Ellydar Chaidir, Negara Hukum, Demokrasi dan Konstalasi Ketatanegaraan Indonesia, Total Media, Yogyakarta, 2007.

Lyman Tower Sargent, Contemporary Political Ideologies, The Dorsey Press, Chicago, 1984, hlm. 123 